\title{
Tracking adhesion factors in Staphylococcus caprae strains responsible for human bone infections following implantation of orthopaedic material
}

\author{
Jeanine Allignet, ${ }^{1}$ Jacques-Olivier Galdbart, ${ }^{1,2}$ Anne Morvan, ${ }^{1}$ \\ Keith G. H. Dyke, ${ }^{1} \dagger$ Pierre Vaudaux, ${ }^{3}$ Sylvie Aubert, ${ }^{1}$ Nicole Desplaces ${ }^{4}$ \\ and Névine El Solh ${ }^{1}$ \\ Author for correspondence: Névine El Solh. Tel: +3314568 83 63. Fax: +33140613163. \\ e-mail: nelsolh $(a$ pasteur.fr
}

\footnotetext{
1 Unité des Staphylocoques, National Reference Center for Staphylococci Institut Pasteur, 72724 Paris Cedex 15, France

2 Service de Microbiologie, Hópital Beaujon, A.P.-H.P., 92100 Clichy, France

3 Division des Maladies Infectieuses, Hôpital Cantonal Universitaire Genève, Switzerland

4 Service de Biologie, Hópital de la Croix-SaintSimon, 75020 Paris, France
}

\begin{abstract}
Ten Staphylococcus caprae strains isolated from four patients and responsible for bone infections following implantation of orthopaedic material were compared to four $\mathbf{S}$. caprae strains collected from milk samples of healthy goats. The following characteristics were investigated: Smal patterns, hybridization patterns with pBA2 (ribotypes), slime production, adhesion to matrix proteins (fibrinogen, fibronectin, collagen) and the staphylococcal adhesion genes (fnbA, clfA, cna, atlE, ica, fbe). None of the characteristics enabled us to distinguish the human strains from the goat strains. Slime was occasionally produced by $S$. caprae strains but all of them carried nucleotide sequences hybridizing at low stringency with the following genes: atIE encoding a S. epidermidis autolysin binding vitronectin and responsible for the primary adhesion to polystyrene, ica operon involved in the biosynthesis of a S. epidermidis extracellular polysaccharide, and the part of clfA encoding the serine-aspartate repeated region of a $S$. aureus cell-wall fibrinogen-binding protein.
\end{abstract}

Keywords: Staphylococcus caprae, bacterial adhesion, autolysin, bone infection, serineaspartate proteins

\section{INTRODUCTION}

It is widely recognized that coagulase-negative staphylococci (CNS), which are major components of the normal flora of the skin and mucous membranes, cause significant clinical infections (Kloos \& Bannerman, 1994; Rupp \& Archer, 1994). Such infections occur mostly after the implantation of foreign materials and/or in immunocompromised patients. The species that most frequently causes disease in humans is Staphylococcus epidermidis, but other coagulase-negative species are increasingly recognized as human pathogens. Staphylococcus caprae was originally isolated from goat's milk (hence the name) (Devriese $e t$ al., 1983) and is predominant among the CNS recovered

†Present address: Microbiology Unit, Dept Biochemistry, University of Oxford, Oxford, UK.

Abbreviations: $\mathrm{CNS}$, coagulase-negative staphylococci; $\mathrm{HP}$, hybridization pattern; MHB, Mueller-Hinton broth; TSB, Trypticase soy broth from mastitis-free goat's milk samples $(55 \%$ of the 165 CNS collected) (Bedidi-Madani et al., 1998a). The CNS of this species are probably widely distributed in human clinical specimens since they accounted for $10.7 \%$ of 1230 staphylococci isolated in six Japanese hospitals and identified by DNA-DNA hybridization (Kawamura et al., 1998). The human S. caprae strains were reported to have been acquired nosocomially following the administration of antibiotics; these strains carry resistance to several antibiotics, including intrinsic resistance to $\beta$-lactams encoded by mecA (Kanda et al., 1991; Kawamura et al., 1998). The involvement of $S$. caprae in human disease (Elsner et al., 1998; Shuttleworth et al., 1997; Spellerberg et al., 1998; Vandenesch et al., 1995) has been reported. The routine use of molecular methods to identify staphylococci at the species level (Chesneau et al., 1992, 1993; De Buyser et al., 1989, 1992) led to the detection, in our reference centre, of $10 \mathrm{~S}$. caprae strains from four patients suffering from bone and joint infections following the implantation of orthopaedic 
material. The aim of this study was to characterize these ten strains and four unrelated $S$. caprae strains isolated from the milk of mastitis-free goats and, in particular, to track the adhesion factors or genes that have been shown to be implicated in the pathogenesis of staphylococci (Bedidi-Madani et al., 1998a; Christensen et al., 1983; Deighton et al., 1996; Greene et al., 1995; Heinz et al., 1996; Hell et al., 1998; Moreillon et al., 1995; Patti et al., 1994; Rupp et al., 1998; Vaudaux et al., 1993).

\section{METHODS}

Patients and analysis of specimens. None of the four patients selected for this study had any contact with goats. Three (patients A, B and C) were infected following the implantation of joint prostheses, whereas the tibia of patient $D$ was infected after osteosynthesis with a plaque and screws (Table 1). The multiple intra-operative specimens (at least three) of patients A, B and D yielded S. caprae only. The knee prosthesis of patient $C$ was originally infected with $S$. epidermidis. One month after the end of a treatment with pefloxacin, rifampin and fusidic acid, there was a secondary infection with $S$. caprae in pure culture. In each case, the infected orthopaedic material had to be removed.

For patient A, the total hip arthroplasty was infected and, despite variations in colony morphology and drug-resistance patterns, all the colonies tested belonged to $S$. caprae. After the removal of the prosthesis, the patient was treated for three months with pefloxacin and fusidic acid. A second prosthesis was implanted five months after the removal of the first and specimens collected during the operation were sterile. The second prosthesis was reinfected with $S$. caprae because of the presence of remaining cement fragments in the distal part of the femur and was removed 19 months after its implantation.

Specimens were cultured on sheep-blood agar for at least $48 \mathrm{~h}$ at $37^{\circ} \mathrm{C}$. The isolated colonies with different morphology from each sample were identified at species level as described previously (De Buyser et al., 1989) and tested using the ID32 Staph System (bioMérieux). Patients whose infected specimens contained only $S$. caprae colonies were included in this study. For each patient, the drug-resistance pattern was determined for colonies of $S$. caprae with different morphology. Strains distinguishable by at least one drug-resistance marker were studied independently.

Bacterial strains and plasmids. The relevant characteristics of the $S$. caprae strains isolated from the specimens of each patient and from milk samples are reported in Table 1. The four $S$. caprae strains isolated from milk samples taken from mastitis-free goats consisted of the type strain, CCM $3573^{\mathrm{T}}$ (Devriese et al., 1983), and three strains previously identified by analysis of their ribotypes (De Buyser et al., 1992): 141-15, $\mathrm{CH} 55$ and $\mathrm{CH} 244$. The following staphylococcal strains were used as positive controls in adhesion, hybridization and PCR experiments: S. aureus Cowan-I (ATCC 12598), S. aureus NCTC 8325 (Novick, 1967), S. aureus Newman (Duthie \& Lorenz, 1952), S. epidermidis RP62A (ATCC 35984) (Christensen et al., 1985) and a clinical isolate of S. epidermidis A6 (this study) carrying the fbe gene (Nilsson et al., 1998). The S. epidermidis strain SP2 (ATCC 35982) (Christensen et al.,

Table 1. Characteristics of the S. caprae strains studied

Abbreviations: As, sodium arsenate; $\mathrm{Cd}$, cadminum acetate; $\mathrm{Cm}$, chloramphenicol; Fm, fosfomycin; Pc, penicillinase production; $\mathrm{Sm}$, streptomycin.

\begin{tabular}{|c|c|c|c|c|c|c|c|c|c|c|}
\hline \multirow[t]{2}{*}{ Patient/specimen } & \multirow[t]{2}{*}{$\begin{array}{c}\text { Strain } \\
\text { designation }\end{array}$} & \multirow[t]{2}{*}{$\begin{array}{l}\text { Drug-resistance } \\
\text { phenotype }\end{array}$} & \multirow[t]{2}{*}{$\begin{array}{l}\text { ID32 Staph } \\
\text { profiles* }\end{array}$} & \multicolumn{2}{|c|}{$\begin{array}{l}\text { Hybridization } \\
\text { patterns with } \\
\text { pBA2 (Fig. 1) }\end{array}$} & \multirow[t]{2}{*}{$\begin{array}{c}\text { Smal } \\
\text { genotype } \\
\text { (Fig. 2) }\end{array}$} & \multirow[t]{2}{*}{$\begin{array}{c}\text { Slime } \\
\text { production }\end{array}$} & \multicolumn{3}{|c|}{$\begin{array}{l}\text { Size }(k b) \text { of } H \text { indIII } \\
\text { fragment hybridizing at } \\
\text { low stringency with: }\end{array}$} \\
\hline & & & & HindIIl & EcoRI & & & $\begin{array}{l}a t l E \\
(\mathrm{~K} / \mathrm{L})\end{array}$ & $\begin{array}{l}i c a \\
(\mathrm{I} / \mathrm{J})\end{array}$ & $\begin{array}{l}\text { clfA-2 } \\
(\mathrm{N} / \mathrm{O})\end{array}$ \\
\hline \multicolumn{11}{|l|}{$\begin{array}{l}\text { Patient A: Tissues around the two hip } \\
\text { prostheses removed during surgery in }\end{array}$} \\
\hline \multirow[t]{3}{*}{ October 1989} & 89318 & $\mathrm{Fm}, \mathrm{Pi}, \mathrm{Cd}, \mathrm{As}$ & $367120000 \dagger$ & $\mathrm{H} 802$ & E804 & 1 & ++ & 3.7 & $1 \cdot 8$ & 3 \\
\hline & 89319 & $\mathrm{Fm}, \mathrm{Pc}, \mathrm{Sm}, \mathrm{Cd}$, As & 362000000 & $\mathrm{H} 802$ & E804 & I & - & 3.7 & 1.8 & 3 \\
\hline & 89320 & Fm, Pc, As & $267330000+$ & $\mathrm{H} 802$ & E804 & 1 & + & 3.7 & 1.8 & 3 \\
\hline \multirow[t]{4}{*}{ Oetoher 1991} & 91.31 .5 & $\mathrm{Fm}, \mathrm{Cd}_{1} \mathrm{As}$ & 367136400 & $\mathrm{H} 802$ & E804 & 1 & - & $3 \cdot 7$ & 1.8 & 3 \\
\hline & 91316 & $\mathrm{Fm}, \mathrm{As}$ & $367136000 \dagger$ & $\mathrm{H} 802$ & E804 & 1 & - & 3.7 & $1 \cdot 8$ & 3 \\
\hline & 91,317 & $\mathrm{Fm}, \mathrm{Pc}_{\mathrm{c}}$ & 367116400 & $\mathrm{H} 802$ & E804 & 1 & + & 3.7 & $1 \cdot 8$ & 3 \\
\hline & 91.318 & $\mathrm{Fm}$ & $363114000 \dagger$ & $\mathrm{H} 802$ & E804 & 1 & - & 3.7 & $1 \cdot 8$ & 3 \\
\hline \multicolumn{11}{|l|}{ Paticnt B: } \\
\hline $\begin{array}{l}\text { Tissues around the hip prosthesis, } \\
\text { removed during surgery }\end{array}$ & 92375 & $\mathrm{Fm}, \mathrm{Pc}, \mathrm{Cd}, \mathrm{As}$ & $36.3336000 \dagger$ & $\mathrm{H} 802$ & $\mathrm{E} 802$ & II & - & $7 \cdot 0$ & 1.8 & $4 / 10$ \\
\hline \multicolumn{11}{|l|}{ Patient $C:$} \\
\hline $\begin{array}{l}\text { Synovial Huid collected during } \\
\text { secondary infection }\end{array}$ & 93161 & $\mathrm{Fm}, \mathrm{Pc}$ & $.36 .3336000 \dagger$ & $\mathrm{H} 800$ & E805 & III & + & $7 \cdot 0$ & $1 \cdot 8$ & $2 \cdot 8 / 3 \cdot 5 / 10$ \\
\hline \multicolumn{11}{|l|}{ Paticnt $\mathrm{D}$ : } \\
\hline $\begin{array}{l}\text { Tissues around orthopaedic material } \\
\text { (screws and plaque, collected during } \\
\text { surgery }\end{array}$ & 96007 & $\mathrm{Fm}, \mathrm{Pc}, \mathrm{Cd}, \mathrm{As}$ & $363136000 \dagger$ & $\mathrm{H} 802$ & E802 & IV & - & $8 \cdot 0$ & $1 \cdot 8$ & $3 \cdot 8 / 11 \cdot 0$ \\
\hline \multirow[t]{4}{*}{ Milk samples from mastitis-frec goats } & $\operatorname{CcM} 353^{\mathrm{T}}$ & $\mathrm{Fm}, \mathrm{As}$ & $265336000 t$ & $\mathrm{H} 800$ & $\mathrm{E} 800$ & vl & + & 3.7 & 1.8 & $2 \cdot 8 / 3 \cdot 5$ \\
\hline & $141 \cdot 15$ & $\mathrm{Fm}, \mathrm{Pc}_{\mathrm{c}} \mathrm{Cm}, \mathrm{Cd}$ & 367136000 & $\mathrm{H} 800$ & E801 & VII & - & 3.7 & 1.8 & $3.75 / 5 / 13$ \\
\hline & CHSS & $\mathrm{Fm}$ & $3671.32000 \dagger$ & $\mathrm{H} 800$ & E801 & VIII & + & 3.7 & 1.8 & $3 \cdot 7 / 11$ \\
\hline & $\mathrm{CH} 1244$ & $\mathrm{Fm}, \mathrm{Pc}, \mathrm{Cd}$ & $365132000+$ & $\mathrm{H} 800$ & E801 & IX & - & 3.7 & 1.8 & $3 \cdot 1$ \\
\hline
\end{tabular}

* Software v2.0 updated in May 1998 by bioMérieux was used for identification.

tConsistent with a 94.5 or a $99.9 \%$ positive identification of $S$. caprae. 
Table 2. Oligonucleotides used for PCR experiments in this study

\begin{tabular}{|c|c|c|c|c|c|}
\hline Primer & Sequence $\left(5^{\prime}-3^{\prime}\right)$ & Gene & $\begin{array}{c}\text { Accession } \\
\text { no. }\end{array}$ & Reference & Position \\
\hline A & GGTAATCATTCATTCGAG & $f n b A$ & J04151 & Signas et al. (1989) & $2362-2379$ \\
\hline $\mathrm{B}$ & TGGCACACTGTCGAAGTC & $f n b A$ & $\mathrm{~J} 04151$ & Signas et al. (1989) & $2568-2551$ \\
\hline C & ATGGTACCAAGAAGATACG & $c n a$ & M81736 & Patti et al. (1992) & $688-705$ \\
\hline $\mathrm{D}$ & TCTTGATACCAAGCTTGTG & $c n a$ & M81736 & Patti et al. (1992) & $1052-1034$ \\
\hline $\mathrm{E}$ & GCACCGGCAGCTGGCAC & clfA & Z18852 & McDevitt et al. (1994) & $974-990$ \\
\hline $\mathrm{F}$ & GCTCATCAGGTTGTTCAGG & $\operatorname{clfA}$ & Z18852 & McDevitt et al. (1994) & $1952-1934$ \\
\hline G & TAAACACCGACGATAATAACCAAA & fbe & Y17116 & Nilsson et al. (1998) & $306-329$ \\
\hline $\mathrm{H}$ & GGTCTAGCCTTATTTTCATATTCA & $f b e$ & Y17116 & Nilsson et al. (1998) & $801-778$ \\
\hline I & GCAGTTACAGGTAATCCACG & $i c a$ & U43366 & Heilmann et al. (1996) & $1235-1254$ \\
\hline $\mathrm{J}$ & СТСТСТTAАСАТCATTCCGACG & $i c a$ & U43366 & Heilmann et al. (1996) & $4089-4110$ \\
\hline $\mathrm{K}$ & CGAAGCAAGTAGCACCTTGG & at $l \mathrm{E}$ & U71377 & Heilmann et al. (1997) & $4142-4161$ \\
\hline $\mathrm{L}$ & CTTGTGCTGACAAGTATTGTGG & at $l \mathrm{E}$ & U71377 & Heilmann et al. (1997) & $6121-6100$ \\
\hline M & GACTTTGAAGAATCTACAC & $f_{n b \mathrm{~A}}$ & J04151 & Signas et al. (1989) & 1948-1966 \\
\hline $\mathrm{N}$ & GATTAAGCTTTACGTTCAAC & clfA & Z18852 & McDevitt et al. (1994) & $1805-1824$ \\
\hline $\mathrm{O}$ & CATTGGTACCATTTTTAGGTG & clfA & Z18852 & McDevitt et al. (1994) & $2948-2928$ \\
\hline
\end{tabular}

1985), which does not produce slime, was used as a negative control. Bacterial suspensions in Brain Heart Infusion containing $15 \%(\mathrm{w} / \mathrm{v})$ glycerol were stored at $-80^{\circ} \mathrm{C}$ until analysis.

The plasmid pBA2 (Iglesias et al., 1983) was used as a probe. It consists of pBR 322 with a $2 \cdot 3 \mathrm{~kb}$ HindIII insert containing the Bacillus subtilis $16 \mathrm{~S}$ rRNA gene. pUC18 was used as a cloning vector.

Susceptibility to antimicrobial agents. The pattern of resistance to antimicrobial agents was determined by the disk diffusion method. The markers tested were those used to detect the known staphylococcal drug-resistance phenotypes. Commercially available disks loaded with the following antibiotics were used: penicillin $G$, oxacillin, spectinomycin, streptomycin, kanamycin, neomycin, gentamicin, tobramycin, chloramphenicol, erythromycin, lincomycin, trimethoprim, sulfonamide, tetracycline, minocycline, pefloxacin, rifampin, fusidic acid, fosfomycin, teicoplanin, vancomycin (Diagnostics Pasteur) and mupirocin (Mast Diagnostics). Additional disks prepared in the laboratory contained $20 \mu \mathrm{g}$ pristinamycin IIA, $40 \mu \mathrm{g}$ pristinamycin IB, $0 \cdot 2 \mu \mathrm{M}$ cadmium acetate, $0.2 \mu \mathrm{M}$ sodium arsenate, $0.2 \mu \mathrm{M}$ mercuric nitrate, $200 \mu \mathrm{g}$ ethidium bromide, $200 \mu \mathrm{g}$ acriflavine, $200 \mu \mathrm{g}$ propamidine isothionate, or $10 \mu \mathrm{g}$ cetyltrimethylammonium bromide.

DNA isolation and analysis. Total cellular DNA was isolated from staphylococcal strains and was purified using the QIAamp tissue kit from Qiagen. Plasmid DNA was extracted and purified from Escherichia coli using the QIAprep spin plasmid kit from Qiagen.

Restriction endonucleases were obtained from Amersham or Pharmacia and were used according to the manufacturer's instructions. Native or digested DNA was analysed by electrophoresis through $0.7 \%$ agarose gels. DNA fragments of less than $1 \mathrm{~kb}$, amplified by PCR, were separated by electrophoresis through $4 \%$ Nusieve agarose gels (FMC).

Blotting and hybridization. DNA was transferred to Hybond$\mathrm{N}+$ membranes and hybridized under stringent conditions $\left(68^{\circ} \mathrm{C}\right.$ ) as previously described (Chesneau et al., 1993), or at lower stringency, i.e. $42^{\circ} \mathrm{C}$ rather than $68^{\circ} \mathrm{C}$.
Ribotype determination. Cellular DNA was extracted, cleaved with HindIII and EcoRI separately, subjected to electrophoresis, transferred onto Hybond- $\mathrm{N}+$ membranes and probed under stringent conditions with $\mathrm{pBA} 2$ radiolabelled with $\left[\alpha^{-32} \mathrm{P}\right] \mathrm{dCTP}\left(110 \mathrm{TBq} \mathrm{mmol}^{-1}\right)$ (De Buyser et al., 1989).

The sizes of the bands constituting the hybridization patterns (HPs) were introduced into our database. Each HP was compared with each of the EcoRI and HindIII HPs previously obtained for validly classified staphylococci (Chesneau et al., 1992; De Buyser et al., 1989, 1992). For each new HP, the percentage similarity to each EcoRI or HindIII HP in the database was calculated. An isolate with a new HP may be assigned to a known taxon if the highest percentages of similarity obtained are clustered within a single taxon.

PCR. The PCR was performed either at high stringency (initial cycle of $5 \mathrm{~min}$ at $95^{\circ} \mathrm{C}$ followed by 30 cycles of $1 \mathrm{~min}$ at $60^{\circ} \mathrm{C}$, $1 \mathrm{~min} 30 \mathrm{~s}$ at $72^{\circ} \mathrm{C}$ and $45 \mathrm{~s}$ at $95^{\circ} \mathrm{C}$ and a final extension step of $10 \mathrm{~min}$ at $72^{\circ} \mathrm{C}$ ) or at low stringency (initial cycle of $5 \mathrm{~min}$ at $95^{\circ} \mathrm{C}$ followed by 30 cycles of $1 \mathrm{~min}$ at $47^{\circ} \mathrm{C}, 1 \mathrm{~min}$ at $72{ }^{\circ} \mathrm{C}$ and $1 \mathrm{~min}$ at $95^{\circ} \mathrm{C}$ with a final extension step of $5 \mathrm{~min}$ at $72^{\circ} \mathrm{C}$ ). The primers used are shown in Table 2 , and were prepared by the phosphoramidite method with an Applied Biosystems model 380B DNA synthesizer. They were used to screen for the presence in $S$. caprae strains, of genes carrying homologous sequences (by PCR at high or low stringency), and to amplify, at high stringency, DNA fragments from the sequenced genes to be used as intragenic probes. The oligonucleotides were chosen so as to amplify: (i) almost all of each gene (ica with oligos I/J and atlE with primers $\mathrm{K} / \mathrm{L}$ ); (ii) the region encoding the part of the protein known to bind the matrix protein (clf $A-1$ with primers $\mathrm{E} / \mathrm{F}$, cna with primers $\mathrm{C} / \mathrm{D}, \mathrm{f} n b A-1$ with primers $\mathrm{B} / \mathrm{M}$ and $f b e$ with primers $\mathrm{G} / \mathrm{H}$ ) and (iii) the region containing repeats (clfA-2 with primers $\mathrm{N} / \mathrm{O}$ and $f n b A-2$ with primers $\mathrm{A} / \mathrm{B}$ ).

The PCR products used as probes were obtained with the following pairs of primers (Table 2): C/D (365 bp from cna of Staphylococcus aureus 8325-4), G/H (496 bp from fbe of $S$. epidermidis A6), I/J (2876 bp from ica of $S$. epidermidis RP62A), K/L (1980 bp from atlE of $S$. epidermidis RP62A), 
M/B (621 bp from fnbA-1 of $S$. aureus 8325-4) and $\mathrm{N} / \mathrm{O}$ (1144 bp from clfA-2 of $S$. aureus 8325-4).

PFGE of macro-restriction fragments. The protocol for the determination of $S m a I$ or SstII restriction patterns was as described previously (Derbise et al., 1996).

DNA sequencing. An Applied Biosystems automated 373A DNA sequencer, and the protocol described by the manufacturer were used for sequencing. The amino acid sequence deduced from the nucleotide sequence was analysed with the GCG package and compared with those deduced from nucleotide sequences in the GenBank/EMBL Database.

Adherence to polystyrene. Adherence to polystyrene, indicating slime production, was quantitatively examined with the spectrophotometric technique as described by Christensen et al. (1985). Overnight cultures in Trypticase soy broth (TSB) were diluted $1: 100$ in fresh TSB and in TSB with glucose $\left(2.5 \mathrm{~g} \mathrm{l}^{-1}\right)$. Portions $(0.2 \mathrm{ml})$ were placed in sterile microtitre polystyrene plates (Becton Dickinson Labware). After overnight incubation at $37^{\circ} \mathrm{C}$, the contents of each well were aspirated and washed four times with $0.2 \mathrm{ml} \mathrm{PBS} \mathrm{(pH} \mathrm{7.2).}$ Adherent organisms were fixed in place with Bouin solution and stained with Huckers crystal violet. Excess stain was rinsed off with running tap water. After the organisms were dried, the optical densities of the stained adherent bacterial films were measured with a MicroElisa Auto Reader at $570 \mathrm{~nm}$.

The measurement was performed in quadruplicate and repeated twice. The positive control strain was $S$. epidermidis RP62A. Means of the raw data were calculated and transformed by the following formula: adherence $=\left(\right.$ mean $\mathrm{OD}_{570}$ after growth in TSB divided by mean $\mathrm{OD}_{\bar{n} \text { in }}$ after growth of $\mathrm{RP62A}$ in TSB $)+\left(\right.$ mean $\mathrm{OD}_{570}$ after growth in TSB with glucose divided by mean $\mathrm{OD}_{\overline{5} 70}$ after growth of RP62A in TSB with glucose).

The adherence value obtained for strain SP2 (ATCC 35982) was 0.38 . For the other strains tested, slime production was designated +++ for adherence values $>2,++$ for values $>1$ and $\leqslant 2$, + for values $>0.5$ and $\leqslant 1$ and the strains with values $\leqslant 0.5$ were considered to be non-producers.

Assessment of in vitro bacterial attachment to coverslips coated with fibrinogen, fibronectin/gelatin or collagen. Adhesion assays were carried out as described by Greene et al. (1995). The strains tested were grown for $5 \mathrm{~h}$ in MuellerHinton broth $(\mathrm{MHB})$ containing $\left[\right.$ methyl $\left.{ }^{3} \mathrm{H}\right]$ thymidine. Twosided coverslips $(8 \times 9 \mathrm{~mm})$ made of polymethylmethacrylate (PMMA) were coated by incubation for $60 \mathrm{~min}$ at $37^{\circ} \mathrm{C}$ with solutions containing $0.5,1$ and $2 \mu \mathrm{g}$ human fibrinogen $\mathrm{ml}^{-1}$ (Chromogenix) or bovine type II collagen (Chemicon). The adsorption of human fibronectin (Chemicon) was optimized by first coating the coverslips with gelatin $\left(1 \mathrm{mg} \mathrm{ml}^{-1}\right)$ (Greene et al., 1995), rinsing them in PBS and incubating them for $60 \mathrm{~min}$ at $37^{\circ} \mathrm{C}$ with solutions containing $0 \cdot 25,0.5$ or $1 \mu \mathrm{g}$ fibronectin $\mathrm{ml}^{-1}$. After incubation of the coated coverslips with $10^{7}$ c.f.u $\left[\right.$ meth $\left.y l^{-3} \mathrm{H}\right]$ thymidine labelled bacteria $\mathrm{ml}^{-1}$ for $60 \mathrm{~min}$ at $37^{\circ} \mathrm{C}$, the number of attached bacteria was estimated from radioactive counts. Uncoated and gelatincoated PMMA coverslips not exposed to matrix proteins were used as controls. Each dose-response curve was produced from at least two experiments, each including a positive control: S. aureus Newman or Cowan-I strains for adhesion to fibrinogen, $S$. aureus Cowan-I for adhesion to fibronectin and to collagen.

Extraction of cell-wall proteins, SDS-PAGE and Western affinity blotting. Cultures were grown at $37^{\circ} \mathrm{C}$ overnight in $50 \mathrm{ml} \mathrm{MHB}$. The overnight culture was then added to $450 \mathrm{ml}$ $\mathrm{MHB}\left(\mathrm{OD}_{600} \sim 0 \cdot 1\right)$ and incubated for $2-3 \mathrm{~h}$ at $37^{\circ} \mathrm{C}$ with shaking at 100 r.p.m. Bacteria $\left(\mathrm{OD}_{600} \sim 0.3-0.4\right)$ were harvested by centrifugation, washed with $20 \mathrm{ml}$ PBS and suspended in $1 \mathrm{ml} 1 \cdot 1 \mathrm{M}$ sucrose in PBS containing $1 \mathrm{mM} \mathrm{CaCl}_{2}$, $0.5 \mathrm{mM} \mathrm{MgCl} \mathrm{M}_{2}$ and $1 / 25$ of a tablet containing a cocktail of protease inhibitors (Complete from Boehringer). Cell-wall proteins were released by treatment with lysostaphin $\left(0.125 \mathrm{mg} \mathrm{ml}^{-1}\right.$ ) (Ambicin L from Applied Microbiology) at $37{ }^{\circ} \mathrm{C}$ for $15 \mathrm{~min}$. The suspension was centrifuged at $12000 \mathrm{~g}$ for $10 \mathrm{~min}$, and the supernatant was concentrated and sucrose eliminated on Centricon-100 (Amicon). Protein concentration was determined by the Bradford protein assay (Bio-Rad).

SDS-PAGE was performed using standard procedures (Laemmli, 1970) with a $5 \%$ polyacrylamide stacking gel and a $6 \%$ resolving gel. Before electrophoresis, $10-30 \mu \mathrm{l}$ of the solutions containing $10-20 \mu \mathrm{g}$ protein released from the cell wall were boiled for $5 \mathrm{~min}$ in $4 \times$ sample buffer $(0.25 \mathrm{M}$ Tris $/ \mathrm{HCl}, \mathrm{pH} 6.8,8 \%$ SDS, $40 \%, \mathrm{v} / \mathrm{v}$, glycerol, $10 \% \beta$ mercaptoethanol and $0.002 \%$ bromophenol blue).

Proteins were transferred electrophoretically onto PVDF membrane (Hybond-P, Amersham) with a Trans-blot cell blotting system (Bio-Rad). The blotting buffer used was $25 \mathrm{mM}$ Tris/ $\mathrm{HCl}, 192 \mathrm{mM}$ glycine and $15 \%$ methanol. Membranes were incubated in TBS blocking reagent $(20 \mathrm{mM}$ Tris/ $\mathrm{HCl}, 500 \mathrm{mM} \mathrm{NaCl}, \mathrm{pH} 7 \cdot 5-8 \cdot 0$ ) containing $2.5 \%$ BSA. Binding proteins were detected by incubating the membranes with $30 \mu \mathrm{g}$ fibronectin $\mathrm{ml}^{-1}$ for $1 \mathrm{~h}$ at room temperature and then with mouse anti-human fibronectin $\mathrm{N}$-terminal monoclonal antibody (Chemicon). Antibodies were detected by chemiluminescence with the ECL kit (Amersham) and antimouse IgG-horseradish peroxidase conjugate.

$\mathrm{N}$-terminal amino acid sequence. The blotted proteins released from the cell wall were stained with amido black. The $\mathrm{N}$-terminal amino acid sequence of an excised band of $175 \mathrm{kDa}$ was determined using an Applied Biosytems 473-A sequencer.

\section{RESULTS}

\section{Identification at the species level}

Using only the ID32 Staph System with a database including $S$. caprae goat strains, only two of the ten human strains, 91316 and 96007 (Table 1), were identified. Taking into account the characteristics of the human strains of S. caprae (Kawamura et al., 1998), five of the ten human strains of this study were correctly assigned to $S$. caprae by the same system (Software v2.0 updated in May 1998) (Table 1). This system failed to identify the other five human strains in the hospital laboratory and in our reference centre. The strains isolated from patient $\mathrm{A}$ had variable biochemical traits (Table 1).

HindIII and EcoRI HPs with pBA2 (ribotypes) were determined for the 14 clinical and goat's milk strains reported in Table 1 . These strains belonged to five ribotypes: H800-E800, H800-E801, H802-E802, H800-E805, H802-E804 (Table 1). All strains isolated from patient $A$ had the same HindIII and EcoRI patterns and the patterns of two clinical isolates, 92375 and 96007, were not distinguishable. Schematic repre- 


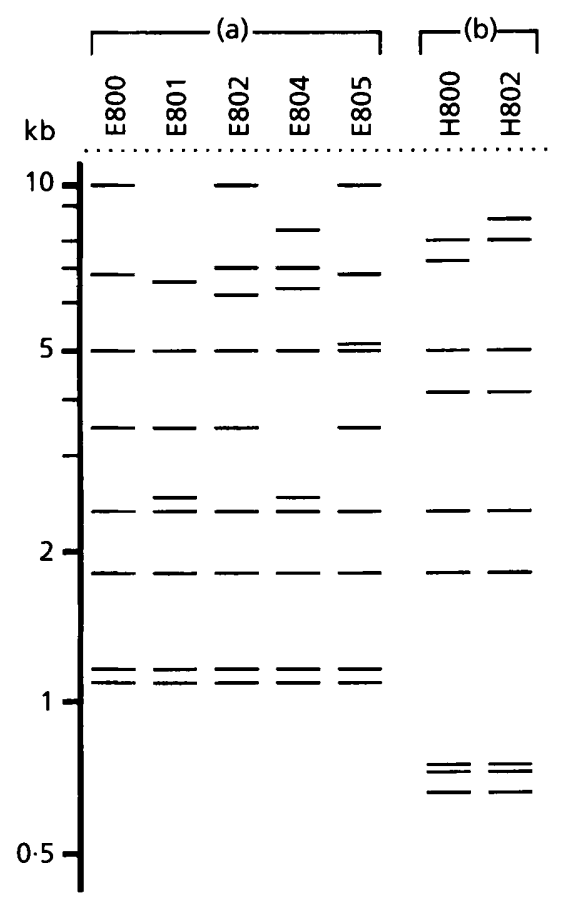

Fig. 1. Schematic representation of the distinct EcoRI or HindIII hybridization patterns, (a) and (b), respectively, detected among the $S$. caprae strains using $\mathrm{pBA} 2$ as probe. The human strains had hybridization patterns H800-E805, H802-E802 or H802-E804 whereas H800-E800 and H800-E801 corresponded to the strains from milk samples.

sentations of each different HP are shown in Fig. 1. The percentage similarities between the HindIII or EcoRI patterns of the human and goat strains of $S$. caprae were very high $(\geqslant 73 \%$ ); therefore, the assignment to $S$. caprae on the basis of HP analysis was straightforward.

\section{Drug-resistance patterns}

All S. caprae strains tested were resistant to fosfomycin (Table 1). Some of the strains carried additional resistance markers: resistance to penicillin by penicillinase production, streptomycin, chloramphenicol, cadmium acetate and sodium arsenate.

\section{Analysis of the Smal macro-restriction patterns}

The patterns of the seven strains isolated from patient $A$ were indistinguishable, suggesting that the strains were monoclonal, although isolated 2 years apart (Table 1 ). The other strains had different genotypes, with differences involving at least seven bands (Fig. 2): they were therefore considered to be polyclonal. This was as expected because no epidemiological links had been found between the patients and/or the goats, which came from different farms.

Although the strains were polyclonal, there were high percentages of similarity between some Smal patterns: $55-78 \%$ between the patterns of the four human strains, $51-75 \%$ between those of the four goat strains and

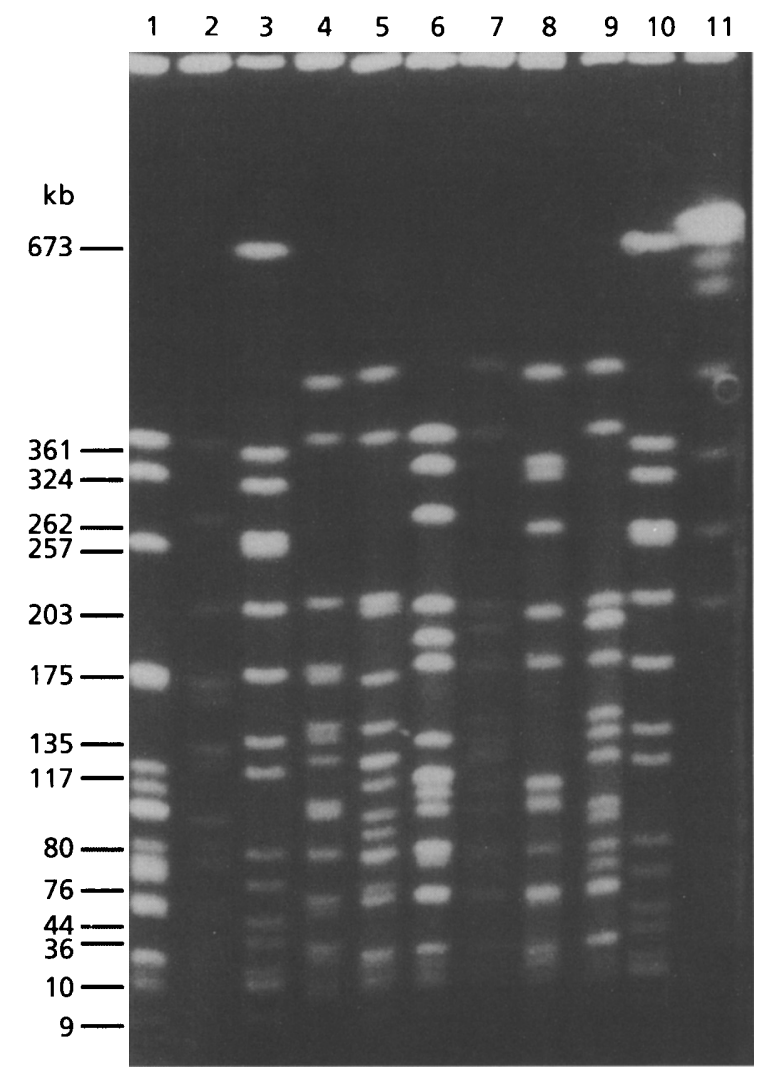

Fig. 2. PFGE of Smal-digested DNA from eight $S$. caprae strains. Lane 1, CCM 3573' ; lane 2, CH244; lane 4, CH55; lane 5, 141-15; lane 6, 93161; lane 7, 92375; lane 8, 89320; lane 9, 96007; lanes 3 and 10, Smal-digested DNA of S. aureus strain NCTC 8325 used as standard and lane 11, bacteriophage lambda DNA concatemers (Bio-Rad). The first four $S$. caprae strains (lanes 1 , 2, 4 and 5) were isolated from goat milk samples whereas the four other strains (lanes 6-9) were isolated from human specimens.

$32-64 \%$ between the human and goat strains. The highest percentages were those for similarity between the patterns of the intra-human or intra-goat $S$. caprae strains.

\section{Slime production}

Four of the ten clinical S. caprae strains and two of the four $S$. caprae strains isolated from milk produced slime (Table 1). Variable results were obtained for the $S$. caprae strains of patient $A$ responsible for the primary and recurrent infections of the hip prosthesis.

\section{In vitro adherence of the $S$. caprae strains to fibronectin/gelatin-, collagen- and fibrinogen-coated coverslips}

Regardless of the matrix protein and concentration used to coat the coverslips, the number of $S$. caprae bacteria adhering to each coverslip was much lower than that for the $S$. aureus Newman or Cowan-I strains included as positive controls. The results obtained with fibronectin/ 

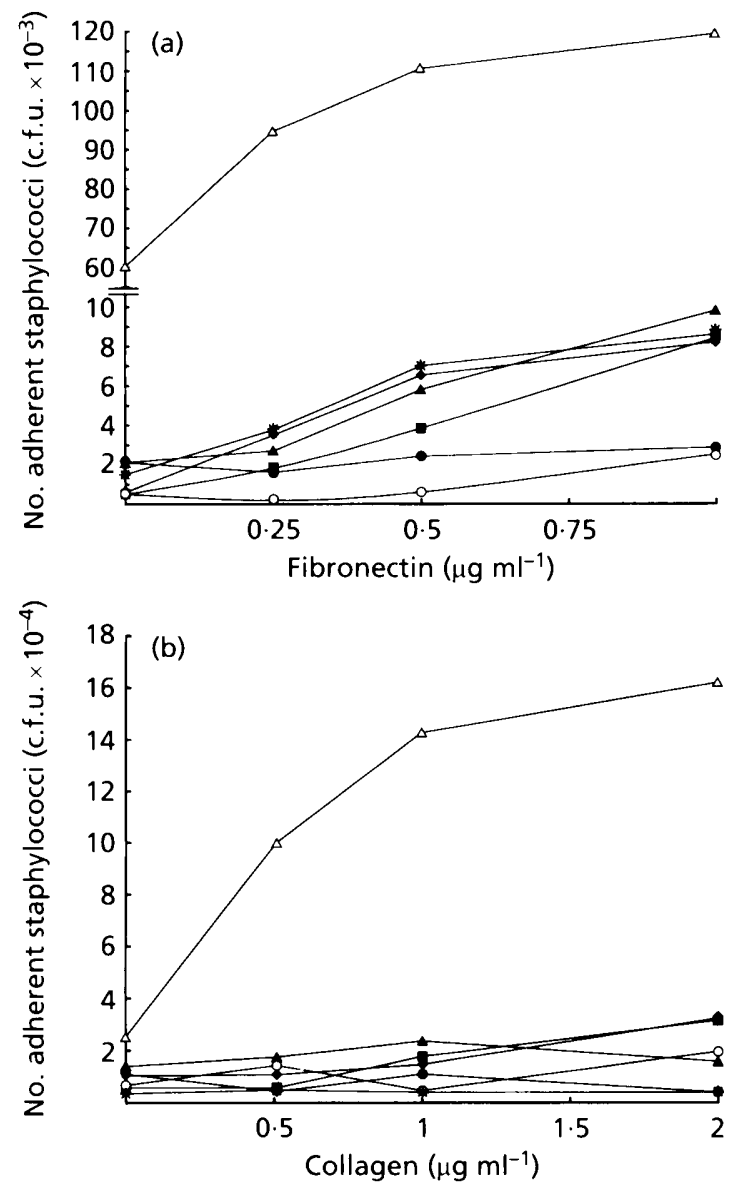

Fig. 3. In vitro adhesion to fibronectin/gelatin-coated coverslips (a) and to collagen-coated coverslips (b) of six S. caprae strains and $S$. aureus Cowan strain used as a positive control. The $S$. caprae strains are indicated as: strain 89320; $\Delta$, strain 92375; 口, strain 93161; O, strain 96007; *, strain 141-15; strain CCM $3573^{\top}$. S. aureus Cowan is represented by $\triangle$.

gelatin- and collagen-coated coverslips are shown in Fig. 3. The human isolates of $S$. caprae could not be distinguished from those collected from goat's milk. The level of adhesion was very low but some $S$. caprae strains adhered in a concentration-dependent fashion: strains $89320,93161,92375,141-15$ and 96007 with fibronectin/ gelatin-coated coverslips (Fig. 3a) and strains 89320 and 93161 with collagen-coated coverslips (Fig. 3b). With fibrinogen-coated coverslips, for each fibrinogen concentration used to coat the coverslips, the ratio of the number of adherent $S$. caprae bacteria per coverslip to that of adherent Newman or Cowan-I bacteria did not exceed $1 / 38$ (results not shown).

\section{Analysis of the proteins released from the bacterial cell wall}

The cell-wall proteins of the four $S$. caprae clinical isolates included in this study and the $S$. caprae type strain were screened for binding to human fibronectin (Fig. 4a). An approximately $175 \mathrm{kDa}$ band was repro- ducibly detected for strains CCM 3573 ${ }^{\mathrm{T}}$, 93161, 92375 and 96007 , and an approximately $97 \mathrm{kDa}$ band was present in the patterns of strains 89320 and 96007 . Strain 89320 was distinguishable from the other strains by the pattern of proteins stained with Coomassie brilliant blue (Fig. 4b).

The N-terminal part of the $\sim 175 \mathrm{kDa}$ protein released from the cell wall of S. caprae strain 96007 (Fig. 4, lane 5 ) was sequenced. The amino acid sequence obtained was AEETQDQTKN, which is $80 \%$ identical to the Nterminal part of $S$. aureus Atl (AETTQDQTTN) (Oshida et al., 1995), 70\% identical to the N-terminal part of Staphylococcus saprophyticus Aas (ASNTQDQTPN) (Hell et al., 1998) and 50\% identical to the same part of $S$. epidermidis AtlE (AEQPQNQSHN) (Heilmann et al., 1997).

\section{Screening for genes encoding staphylococcal adhesion factors}

PCR experiments were carried out with primers based on the sequences of the genes $f n b A, c n a, c l f A$ and $f b e$ (Table 2). None of the $S$. caprae strains gave rise to a PCR product at high stringency $\left(60^{\circ} \mathrm{C}\right)$. At lower stringency $\left(47^{\circ} \mathrm{C}\right)$, PCR products were occasionally detected but their sizes were consistently different from those expected if the intact sequenced genes investigated were present and their sequences did not have significant similarities to any of the sequenced adhesion factors (results not shown). We concluded that low stringency PCR was not a productive way of isolating genes for the adhesion factors of $S$. caprae. We therefore decided to use hybridization experiments to detect the presence of genes homologous to atlE, ica, fnbA, cna, clfA and fbe. At low stringency $\left(42{ }^{\circ} \mathrm{C}\right)$, sequences hybridizing to atlE, ica and clfA-2 were detected in all strains tested. The sizes of the HindIII fragments hybridizing to these probes are reported in Table 1 . Some $S$. caprae strains had several HindIII fragments that hybridized at low stringency to the clfA-2 DNA encoding the serineaspartate dipeptide repeat of ClfA.

\section{DISCUSSION}

\section{Identification of S. caprae}

Ecological studies and the recognition of $S$. caprae as a human pathogen have probably been thwarted by difficulties in the precise identification of this species by available phenotypic schemes. Such difficulties in phenotypic identification are not restricted to the human isolates (this study; Kawamura et al., 1998; Shuttleworth et al., 1997; Vandenesch et al., 1995) but are also encountered for goat isolates (Bedidi-Madani et al., 1998b). As illustrated here, there has been a significant improvement in the identification of human S. caprae strains by the ID32 Staph System, taking into account the emended description of this species (Kawamura et al., 1998). Resistance to fosfomycin shown by all the strains studied here and by those described by other authors (Elsner et al., 1998; 
(a)

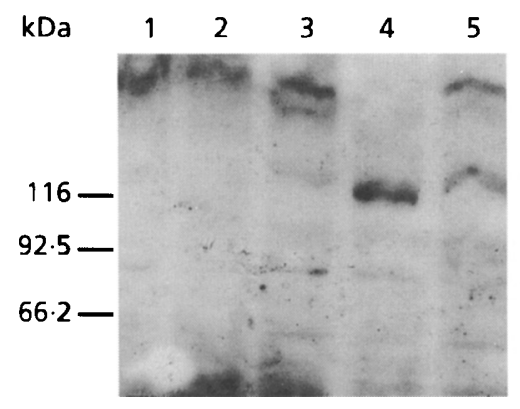

(b)

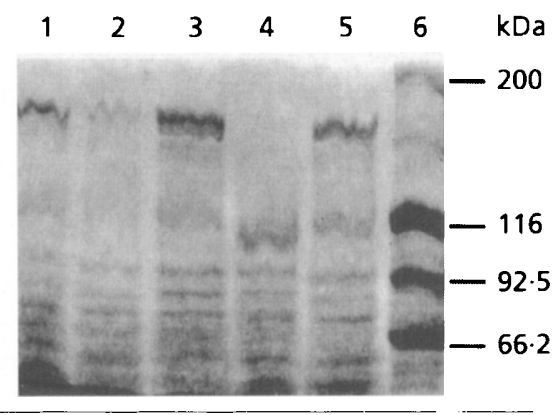

Fig. 4. SDS-PAGE analysis of the proteins released from the cell walls of $S$. caprae strains: CCM 3573 (lane 1), 93161 (lane 2), 92375 (lane 3), 89320 (lane 4) and 96007 (lane 5). (a) Fibronectin-binding proteins; (b) proteins stained with Coomassie brilliant blue. The high molecular-mass standard (Bio-Rad) was loaded in lane 6.
Vandenesch et al., 1995) may be a useful presumptive test for the identification of $S$. caprae but several other staphylococcal species, such as $S$. saprophyticus, Staphylococcus hominis, Staphylococcus capitis and Staphylococcus auricularis have natural resistance to this antibiotic (Loulergue et al., 1984).

Although none of the four patients had any direct or indirect contact with goats, none of the phenotypic and genomic characteristics investigated distinguished the human infectious $S$. caprae strains from those isolated from the milk samples of mastitis-free goats. The slight difference between the $S m a I$ patterns of human and goat S. caprae strains reported by George \& Kloos (1994) was also detected for the strains of this study but neither Smal patterns nor ribotypes gave clear-cut discrimination.

Molecular methods such as the analysis of ribotypes (Vandenesch et al., 1995), sequencing of the 16S rRNA gene (Spellerberg et al., 1998), DNA-DNA hybridization (George \& Kloos, 1994; Kawamura et al., 1998) and the analysis of the banding patterns on gels of penicillinbinding proteins (Kanda et al., 1991) have been used to detect $S$. caprae in various specimens from humans and to determine its involvement in human pathology. Seven previously documented cases of human infections with $S$. caprae have been reported (Elsner et al., 1998; Spellerberg et al., 1998; Vandenesch et al., 1995): one case of endocarditis with macroscopic evidence of intraventricular vegetation, three cases of bacteraemia (one adult patient with catheter-associated sepsis and two neonates with cardiac malformations), two cases of symptomatic urinary tract infections in the absence of urethral catheter and one case of an intra-articular empyema following arthroscopic cruciate ligament repair in an adult immunocompetent patient.

\section{Involvement of S. caprae in bone and joint infections}

Frequent associations of $S$. caprae strains with bone and joint infections were reported by Shuttleworth et al. (1997) (10 of the 14 cases of human infections). In eight of the ten cases of bone and joint infections, the clinical significance of $S$. caprae was unclear because it was detected along with other pathogens in the same specimen. Moreover, its detection in several specimens from the same patient indicated that it was persistently present in the infected lesions and had a possible predilection for bone sites. In our study, the four cases of human bone and joint infections following the implantation of orthopaedic material could be attributed to $S$. caprae strains detected in pure cultures in at least three specimens from the same patient. In each case, the orthopaedic material had to be removed 7-19 months after implantation. The recurrent infection of patient $\mathrm{A}$ (Table 1 ) was due to a single $S$. caprae strain with variations in the appearence of colonies, biochemical traits, slime production and drug-resistance patterns. The strain responsible for the recurrent infection was susceptible to the antibiotics used to treat the primary infection, so recurrence was not due to the selection of a resistant variant. For one of the four patients (patient $C$, Table 1), $S$. caprae infection of the knee prosthesis occurred one month after the end of antibiotic treatment for a primary infection caused by S. epidermidis. In this case too, the $S$. caprae strain responsible for the secondary infection was susceptible to the drugs used to treat the primary infection.

\section{Adhesion factors and genes in S. caprae}

Four of the ten human strains tested in this study produced slime, as did $33 \%$ of 165 goat S. caprae strains including the type strain, CCM $3573^{\mathrm{T}}$, tested in a previous study (Bedidi-Madani et al., 1998a). Phase variation in the expression of in vitro slime production has been reported in S. epidermidis strains (Baddour et al., 1990; Christensen et al., 1990; Deighton et al., 1992; Ziebuhr et al., 1997) and similar phase variation in $S$. caprae may account for the variable expression of this trait, in particular among the seven monoclonal strains of patient A. All the strains studied here, whether or not they produced slime, had nucleotide sequences that hybridized at low stringency (i) to the S. epidermidis atlE gene (Heilmann et al., 1997; Rupp et al., 1998) which encodes an autolysin binding vitronectin and responsible for the primary attachment to polystyrene, and for an increased virulence in a rat central venous catheterassociated infection model and (ii) to the S. epidermidis ica operon (Heilmann et al., 1996) involved in the biosynthesis of an extracellular polysaccharide (PIA) (Mack et al., 1996) and a capsular polysaccharide antigen called PS/A (McKenney et al., 1998). Slime production may contribute to the virulence of $S$. caprae and to its protection against antibiotic access to the bacterium, as it does in S. epidermidis (Christensen et 
al., 1983; Deighton et al., 1996). The slime produced by some of the bacteria derived from the $S$. caprae strain of patient A may be why this strain was not eradicated by antibiotics. Alternatively, resistance to antibiotic treatment may be due to the segregation of a small-colony variant subpopulation of $S$. caprae. Such variants were shown to give $S$. aureus great flexibility favouring survival and making it difficult to cure infections in intra-vascular and bone sites despite the maintenance of antibiotic treatment over long time periods (Proctor \& Peters, 1998).

There is increasing evidence that staphylococcal autolysins are important in pathogenesis (Hell et al., 1998; Mani et al., 1994; Rupp et al., 1998). Three similar genes in $S$. aureus, $S$. epidermidis and $S$. saprophyticus encoding cell-wall-associated autolysins have been sequenced: atl (Oshida et al., 1995, 1998), atlE (Heilmann et al., 1997) and aas (Hell et al., 1998), respectively. The three proteins encoded by these genes have two enzymic domains (amidase and glucosaminidase) in common. S. epidermidis AtIE binds to polystyrene and vitronectin whereas the $S$. saprophyticus Aas binds to fibronectin and sheep erythrocytes. The domain of Aas that binds to fibronectin and sheep erythrocytes is located between the two enzymic domains (Hell et al., 1998). This prompted us to check whether the cell-wall fibronectin-binding proteins detected in all the $S$. caprae strains tested (Fig. 4) are encoded by the putative autolysin genes. N-terminal sequencing of the $\sim 175 \mathrm{kDa}$ protein of $S$. caprae strain 96007, which binds fibronectin, confirmed this assumption because the first ten amino acids were $80 \%$ identical to the corresponding sequence of the $S$. aureus Atl.

None of the $S$. caprae strains produced a clumping factor or showed any significant adhesion in vitro to fibrinogen but we cannot exclude the possibility that the genomes of all the strains contain several genes encoding fibrinogen-binding proteins, because several HindIII fragments were detected that hybridized at low stringency with clfA-2, encoding the serine-aspartate (SD) repeats of ClfA (Josefsson et al., 1998; McDevitt et al., 1994, 1995). If the hybridizing sequences are parts of genes encoding SD-repeat proteins, then it is a similar situation to that observed with the chromosome of $S$. aureus Newman strain hybridized with a probe for the SD-repeat region of $c l f A$ (Josefsson $e t$ al., 1998). Two of these genes were clfA (McDevitt et al., 1994) and cflB (Ni Eidhin et al., 1998) which encode proteins binding the $\delta$ and $\alpha / \beta$ chains of fibrinogen, respectively, and the three other genes $(s d r C, s d r B, s d r E$ ) (Josefsson et al., 1998) encode proteins suspected to interact with host proteins because of their organizational and sequence similarity with $c l f A$ and $c l f B$.

\section{Conclusions}

This study enabled us to reveal, in addition to a gene encoding a new member of the serine-aspartate repeat protein family, atlE and ica genes in human and goat strains of $S$. caprae. These latter genes are probably somewhat different from those used as probes because they were detected at low stringency only. All these genes should be isolated by cloning so that they can be characterized and their contribution to pathogenicity evaluated in animal models.

\section{ACKNOWLEDGEMENTS}

We thank Jacques d'Alayer and Marilyne Davi for advice on protein sequencing, Manuela Bento for help with adhesion assays and Catherine Tran for secretarial assistance. Keith Dyke thanks the Wellcome Trust for a Travelling Research Fellowship. Pierre Vaudaux was supported by grant 320$045810.95 / 1$ from the Swiss National Foundation for Scientific Research.

\section{REFERENCES}

Baddour, L. M., Barker, L. P., Christensen, G. D., Parisi, J. T. \& Simpson, W. A. (1990). Phenotypic variation of Staphylococcus epidermidis in infection of transvenous endocardial pacemaker electrodes. J Clin Microbiol 28, 676-679.

Bedidi-Madani, N., Greenland, T. \& Richard, Y. (1998a). Exoprotein and slime production by coagulase-negative staphylococci isolated from goats' milk. Vet Microbiol 59, 139-145.

Bedidi-Madani, N., Kodjo, A., Villard, L. \& Richard, Y. (1998b). Ribotyping of Staphylococcus caprae isolated from goat milk. Vet Res 29, 149-158.

Chesneau, O., Aubert, S., Morvan, A., Guesdon, J. L. \& El Solh, N. (1992). Usefulness of the ID32 Staph system and a method based on $\mathrm{R}$ RA gene restriction site polymorphism analysis for species and subspecies identification of staphylococcal clinical isolates. $J$ Clin Microbiol 30, 2346-2352.

Chesneau, O., Allignet, J. \& El Solh, N. (1993). Thermonuclease gene as a target nucleotide sequence for specific recognition of Staphylococcus aureus. Mol Cell Probes 7, 301-310.

Christensen, G. D., Simpson, W. A., Bisno, A. L. \& Beachey, E. H. (1983). Experimental foreign body infections in mice challenged with slime-producing Staphylococcus epidermidis. Infect Immun 40, 407-410.

Christensen, G. D., Simpson, W. A., Younger, J. L., Baddour, L. M., Barrett, F. F., Melton, D. M. \& Beachy, E. H. (1985). Adherence of coagulase-negative staphylococci to plastic tissue culture plates: a quantitative model for the adherence of staphylococci to medical devices. J Clin Microbiol 22, 996-1006.

Christensen, G. D., Baddour, L. M., Madison, B. M., Parisi, J. T., Abraham, S. N., Hasty, D. L., Lowrance, J. H., Josephs, J. A. \& Simpson, W. A. (1990). Colonial morphology of staphylococci on memphis agar: phase variation of slime production, resistance to $\beta$-lactam antibiotics, and virulence. J Infect Dis 161, 1153-1169.

De Buyser, M. L., Morvan, A., Grimont, F. \& El Solh, N. (1989). Characterization of Staphylococcus species by ribosomal RNA gene restriction patterns. J Gen Microbiol 135, 989-999.

De Buyser, M. L., Morvan, A., Aubert, S., Dilasser, F. \& El Solh, N. (1992). Evaluation of a ribosomal RNA gene probe for the identification of species and subspecies within the genus Staphylococcus. J Gen Microbiol 138, 889-899.

Deighton, M., Pearson, S., Capstick, J. A., Spelman, D. \& Borland, R. (1992). Phenotypic variation of Staphylococcus epidermidis isolated from a patient with native valve endocarditis. $J$ Clin Microbiol 30, 2385-2390. 
Deighton, M., Borland, R. \& Capstick, J. A. (1996). Virulence of Staphylococcus epidermidis in a mouse model: significance of extracellular slime. Epidemiol Infect 117, 267-280.

Derbise, A., Dyke, K. G. H. \& El Solh, N. (1996). Characterization of a Staphylococcus aureus transposon $\operatorname{Tn} 5405$, located within Tn5404 and carrying the aminoglycoside resistance genes, $a p h A$ 3 and aadE. Plasmid 35, 174-188.

Devriese, L. A., Poutrel, B., Killper-Bälz, R. \& Schleifer, K. H. (1983). Staphylococcus gallinarum and Staphylococcus caprae, two new species from animals. Int J Syst Bacteriol 33, 480-486.

Duthie, E. S. \& Lorenz, L. L. (1952). Staphylococcal coagulase: mode of action and antigenicity. J Gen Microbiol 6, 95-107.

Elsner, H.-A., Dahmen, G. P., Laufs, R. \& Mack, D. (1998). Intraarticular empyema due to Staphylococcus caprae following arthroscopic cruciate ligament repair. J Infect 37, 66-67.

George, C. G. \& Kloos, W. E. (1994). Comparison of the SmaIdigested chromosomes of Staphylococcus epidermidis and the closely related species Staphylococcus capitis and Staphylococcus caprae. Int J Syst Bacteriol 44, 404-409.

Greene, C., McDevitt, D., Francois, P., Vaudaux, P. E., Lew, D. P. \& Foster, T. J. (1995). Adhesion properties of mutants of Staphylococcus aureus defective in fibronectin-binding proteins and studies on the expression of $f n b$ genes. Mol Microbiol 17, 1143-1152.

Heilmann, C., Schweitzer, O., Gerke, C., Vanittanakom, N., Mack, D. \& Gotz, F. (1996). Molecular basis of intercellular adhesion in the biofilm-forming Staphylococcus epidermidis. Mol Microbiol 20, 1083-1091.

Heilmann, C., Hussain, M., Peters, G. \& Götz, F. (1997). Evidence for autolysin-mediated primary attachment of Staphylococcus epidermidis to a polystyrene surface. Mol Microbiol 24, 1013-1024.

Heinz, S. A., Schennings, T., Heimdahl, A. \& Flock, J.-L. (1996). Collagen binding of Staphylococcus aureus is a virulence factor in experimental endocarditis. J Infect Dis 174, 83-88.

Hell, W., Meyer, H.-G. W. \& Gatermann, S. G. (1998). Cloning of aas, a gene encoding a Staphylococcus saprophyticus surface protein with adhesive and autolytic properties. Mol Microbiol 29, 871-881.

Iglesias, A., Ceglowski, P. \& Trautner, T. A. (1983). Plasmid transformation in Bacillus subtilis: effects of the insertion of Bacillus subtilis rRNA genes into plasmids. Mol Gen Genet 192, 149-155.

Josefsson, E., McCrea, K. W., Ni Eidhin, D., O'Connell, D., Cox, J., Hobk, M. \& Foster, T. J. (1998). Three new members of the serineaspartate repeat protein multigene family of Staphylococcus aureus. Microbiology 144, 3387-3395.

Kanda, K., Suzuki, E., Hiramatsu, K., Oguri, T., Miura, H., Ezaki, T. \& Yokota, T. (1991). Identification of a methicillin-resistant strain of Staphylococcus caprae from a human clinical specimen. Antimicrob Agents Chemother 35, 174-176.

Kawamura, Y., Hou, X.-G., Sultana, F., Hirose, K., Miyake, M., Suh, S.-E. \& Ezaki, T. (1998). Distribution of Staphylococcus species among human clinical specimens and emended description of Staphylococcus caprae. J Clin Microbiol 36, 2038-2042.

Kloos, W. E. \& Bannerman, T. L. (1994). Update on clinical significance of coagulase-negative staphylococci. Clin Microbiol Rev 7, 117-140.

Laemmli, U. K. (1970). Cleavage of structural proteins during the assembly of the head of bacteriophage T4. Nature 227, 680-685.

Loulergue, J., Pinon, G., Laudat, P. \& Audurier, A. (1984). Fosfomycin resistance in Staphylococcus saprophyticus and other species of coagulase-negative staphylococci. Ann Microbiol 135A, 239-247.

McDevitt, D., Francois, P., Vaudaux, P. \& Foster, T. J. (1994). Molecular characterization of the clumping factor (fibrinogen receptor) of Staphylococcus aureus. Mol Microbiol 11, 237-248.

McDevitt, D., Francois, P., Vaudaux, P. \& Foster, T. J. (1995). Identification of the ligand-binding domain of the surface-located fibrinogen receptor (clumping factor) of Staphylococcus aureus. Mol Microbiol 16, 895-907.

Mack, D., Fischer, W., Krokotsch, A., Leopold, K., Hartmann, R., Egge, H. \& Laufs, R. (1996). The intercellular adhesin involved in biofilm accumulation of Staphylococcus epidermidis is a linear $\beta$ 1,6-linked glucosaminoglycan: purification and structural analysis. J Bacteriol 178, 175-183.

McKenney, D., Hubner, J., Muller, E., Wang, Y., Goldmann, D. A. \& Pier, G. B. (1998). The ica locus of Staphylococcus epidermidis encodes production of the capsular polysaccharide/adhesin. Infect Immun 66, 4711-4720.

Mani, N., Baddour, L. M., Offutt, D. Q., Vijaranakul, U., Nadakavukaren, M. J. \& Jayaswal, R. K. (1994). Autolysis-defective mutant of Staphylococcus aureus: pathological considerations, genetic mapping, and electron microscopic studies. Infect Immun 62, 1406-1409.

Moreillon, P., Entenza, J. M., Francioli, P., McDevitt, D., Foster, T. J., François, P. \& Vaudaux, P. (1995). Role of Staphylococcus aureus coagulase and clumping factor in pathogenesis of experimental endocarditis. Infect Immun 63, 4738-4743.

Ni Eidhin, D., Perkins, S., François, P., Vaudaux, P., Hø̋́k, M. \& Foster, T. J. (1998). Clumping factor B (ClfB), a new surfacelocated fibrinogen-binding adhesin of Staphylococcus aureus. Mol Microbiol 30, 245-257.

Nilsson, M., Frykberg, L., Flock, J. I., Pei, L., Lindberg, M. \& Guss, B. (1998). A fibrinogen-binding protein of Staphylococcus epidermidis. Infect Immun 66, 2666-2673.

Novick, R. P. (1967). Properties of a cryptic high frequency transducing phage in S. aureus. Virology 33, 155-166.

Oshida, T., Sugai, M., Komatsuzawa, H., Hong, Y.-M., Suginaka, H. \& Tomasz, A. (1995). A Staphylococcus aureus autolysin that has an $N$-acetylmuramoyl-L-alanine amidase domain and an endo- $\beta$ - $N$-acetylglucosaminidase domain: cloning, sequence analysis, and characterization. Proc Natl Acad Sci USA 92, 285-289.

Oshida, T., Takano, M., Sugai, M., Suginaka, H., Matsushita, T. (1998). Expression analysis of the autolysin gene (atl) of Staphylococcus aureus. Microbiol Immunol 42, 655-659.

Patti, J. M., Jönsson, H., Guss, B., Switalski, L. M., Wiberg, K., Lindberg, M. \& Hobk, M. (1992). Molecular characterization and expression of a gene encoding a Staphylococcus aureus collagen adhesin. J Biol Chem 267, 4766-4772.

Patti, J. M., Bremell, T., Krajewska-Pietrasik, D., Abdelnour, A., Tarkowski, A., Rydén, C. \& Hoök, M. (1994). The Stapbylococcus aureus collagen adhesin is a virulence determinant in experimental septic arthritis. Infect Immun 62, 152-161.

Proctor, R. A. \& Peters, G. (1998). Small colony variants in staphylococcal infections: diagnostic and therapeutic implications. Clin Infect Dis 27, 419-423.

Rupp, M. E. \& Archer, G. L. (1994). Coagulase-negative staphylococci: pathogens associated with medical progress. Clin Infect Dis 19, 231-243.

Rupp, M. E., Ulphani, J. S., Fey, P. D., Heilmann, C. \& Gotz, F. (1998). Characterization of Staphylococcus epidermidis O-47 and an isogenic autolysin-deficient mutant in a rat central venous 
catheter (CVC)-associated infection model. Abstracts of the 38th International Conference on Antimicrobial Agents and Chemotherapy, 24-27 September, San Diego, California. Abstract B-23.

Shuttleworth, R., Behme, R. J., McNabb, A. \& Colby, W. D. (1997). Human isolates of Staphylococcus caprae: association with bone and joint infections. J Clin Microbiol 35, 2537-2541.

Signas, C., Raucci, G., Jonsson, K., Lindgren, P. E., Anantharamaiah, G. M., Höök, M. \& Lindberg, M. (1989). Nucleotide sequence of the gene for a fibronectin-binding protein from Staphylococcus aureus: use of this peptide sequence in the synthesis of biologically active peptides. Proc Natl Acad Sci USA 86, 699-703.

Spellerberg, B., Steidel, K., Lütticken, R. \& Haase, G. (1998). Isolation of Staphylococcus caprae from blood cultures of a neonate with congenital heart disease. Eur J Clin Microbiol Infect Dis $17,61-62$.
Vandenesch, F., Eykyn, S. J., Bes, M., Meugnier, H., Fleurette, J. \& Etienne, J. (1995). Identification and ribotypes of Staphylococcus caprae isolates isolated as human pathogens and from goat milk. J Clin Microbiol 33, 888-892.

Vaudaux, P., Pittet, D., Haeberli, A., Lerch, P. G., Morgenthaler, J. J., Proctor, R. A., Waldvogel, F. A. \& Lew, D. P. (1993). Fibronectin is more active than fibrin or fibrinogen in promoting Staphylococcus aureus adherence to inserted intravascular catheters. J Infect Dis 167, 633.

Ziebuhr, W., Heilmann, C., Götz, F., Meyer, P., Wilms, K., Straube, E., Hacker, J. (1997). Detection of the intercellular adhesion gene cluster (ica) and phase variation in Staphylococcus epidermidis blood culture strains and mucosal isolates. Infect Immun 65, 890-896.

Received 18 January 1999; revised 26 April 1999; accepted 7 May 1999. 